resolution of the lesions. It has been reported (Emslie, Cross, and Blake, 1962) that penicillin chewing-gum is the treatment of choice and that this therapy results in rapid resolution of the lesions. However, there are many who would condemn the use of penicillin in such a fashion (Anderson, 1961), particularly because of the dangers of sensitization to penicillin and possibly of producing resistance in other organisms in the mouth. Recently, objections to systemic penicillin in dental practice have also been pointed out (Canad. med. Ass. F., 1962).

It was an incidental observation that directed attention to the use of metronidazole for this condition, and there is little doubt that this compound when given orally is effective clinically and active against the organisms of Vincent's infection. It is not yet clear whether it is the presence of the compound in the saliva or the presence of the compound in the serum, the concentration of which reaches $4.8 \mu \mathrm{g} . / \mathrm{ml}$. one hour after the oral administration of $200 \mathrm{mg}$. (Kane, McFadzean, Squires, King, and Nicol, 1961), or both, that is responsible for the clinical effect.

Metronidazole is a well-tolerated compound which has now been administered to tens of thousands of patients for the treatment of trichomoniasis without side-effects, and it would appear to provide a simple and safe therapy for Vincent's infections.

\section{Summary}

Fifteen patients with Vincent's stomatitis were treated with metronidazole. In 14 of the 15 , clinical resolution of the lesions was rapid, and healing was usually complete within three days. The spirochaetes disappeared within 24 hours, but the disappearance of the fusiform organisms was slower.

Metronidazole is active in vitro against the spirochaetes and against one strain of Bacteroides.

It is not clear if the compound acts by virtue of its presence in the serum or in the saliva, or in both.

It is suggested that it provides an effective form of therapy without the disadvantages of penicillin.

\section{REFERENCES}

Anderson, $T$ (1961). In Textbook of Medical Treatment, edited by D. M. Dunlop et al., 8th ed., p. 72. Livingstone, Edinburgh. Canad. med. Ass. F., 1962, 87, 569.

Emslie, R. D., Cross, W. G., and Blake, G. C. (1962). Brit. dent. F., 112, 320.

Kane, P. O. (1961). 7. Polarog. Soc., 7, 58.

McFadzean, J. A., Squires, S., King, A. J., and Nicol, C. S. (1961)

Brit. F. vener. Dis., 37, 273.

Shinn, D. L. S. (1962). Lancet, 1, 1191.

\title{
Maximal Tubular Resorptive Rate for Inorganic Phosphate in Hyperparathyroidism
}

\author{
J. ANDERSON,* M.D., F.R.C.P., B.SC. ; V. PARSONS,* B.M., M.R.C.P.
}

Primary hyperparathyroidism is difficult to recognize when the increased plasma-calcium concentration varies so that it may be within the normal range at times though a tumour is present. Similarly, hypercalciuria is not always found because of renal failure. Moreover, some patients with normal renal function and a raised concentration of calcium in the plasma do not have hypercalciuria. The result is that there is often a need for additional biochemical support before the diagnosis can be established.

In the earlier studies of primary hyperparathyroidism, hyperphosphaturia and hypophosphataemia were found to be characteristic in the absence of renal failure. Albright and Ellsworth (1929) thought the reduced renal resorption of phosphate was the prime effect of parathyroid hormone, changes in calcium metabolism following it. This view was challenged when Collip, Pugsley, Selye, and Thomson (1934) injected parathormone into nephrectomized rats and found a rise in serum-calcium concentration. From this time evidence has accumulated that the main function of the hormone is to raise the ionized-calcium concentration in the plasma by acting directly on bone, and by reversing the protein binding of the ionic calcium (Lloyd, Rose, and Smeenk, 1962). When parathormone is present in excess, whether experimentally or clinically, changes in renal-phosphate excretion must be interpreted against this background of its primary action on the concentration of ionized-calcium in the plasma. Because this is difficult to measure accurately and also because there are many other causes of hypercalcaemia, we have studied the effects of hyperparathyroidism on phosphate excretion with the aim of providing a supplementary method of diagnosis.
In primary hyperparathyroidism Sirota (1953) found in two patients that the maximal resorptive rate for phosphate was depressed, returning to normal after the adenomas were removed. He attributed the alteration mainly to changes in glomerular filtration rate. Anderson (1955a) reported four more patients who had their TmP determined before and after removal of their tumours, in whom the elevation of the TmP to normal values could not be explained by changes in filtration rate and appeared to be due to removal of the tumour. Hiatt and Thompson (1957) confirmed these findings in another patient and also demonstrated a lowered TmP in normal subjects on giving parathormone intravenously. Hyde, Vaughan Jones, McSwiney, and Prunty (1960), however, reported a further series from which they felt that estimation of the TmP was not a reliable way of confirming a diagnosis of hyperparathyroidism because the values fluctuated widely, tending also to change as the test proceeded, possibly because of the high concentration of inorganic phosphorus in the plasma reached during their infusions.

A group of patients with proved hyperparathyroidism were investigated to show the possible usefulness in diagnosis of phosphate clearances under intravenous phosphate loading. The method of determining the TmP has been improved by doing clearances at two raised constant plasma-phosphate concentrations so that a statistical determination of the error could be made and the effect of raising the plasma-phosphate concentration in two steps could be determined.

\footnotetext{
* Department of Medicine, King's College Hospital Medical School, London.
} 


\section{Clinical Material and Methods}

Fourteen patients who had parathyroid tumours removed at operation had their TmP investigated, four on a second occasion during a cortisone-suppression test and six again after removal of their parathyroid adenoma. Many of the patients had impaired renal function attributable to the primary hyperparathyroidism alone in some and in others partly to hypertension, pyelonephritis, or renal calculi.

The clinical conditions during the estimations, the means of raising the plasma-phosphate concentration, and the chemical methods used were those described by Anderson (1955b) and Anderson and Parsons (1963a). All the patients were kept on a normal phosphate intake ( 1 to $1.5 \mathrm{~g}$. phosphorus daily) for several days before the test, most of them being on a constant balance diet for other investigations. The phosphate and inulin infusions were given in the early morning while fasting, P.A.H. was not given as it was not desired to measure renal plasma flow and P.A.H. is known to affect TmP. Plasma-phosphate concentrations were restricted to a maximum of $11 \mathrm{mg} . / 100 \mathrm{ml}$. with the exception of patient 13, who will be discussed later. Clearances were done without catheterization during ascending steps of the plasma-phosphate concentration. A maximal diuresis was established with oral loading $(20 \mathrm{ml} . / \mathrm{kg} . / \mathrm{hr}$.), supplemented by the infusions of saline and phosphate.

\section{Results}

Table 1 gives the results of a typical clearance run on patient 11 , showing how the $\operatorname{TmP}$ is calculated by subtracting the urinary phosphate from the filtered phosphate, determined by the product of the inulin clearance and the plasma inorganic phosphorus, assuming that all the plasma phosphorus is ultrafiltrable. The patient's plasma-phosphorus concentration did not rise above $7.5 \mathrm{mg} . / 100 \mathrm{ml}$. and there was no significant difference between the TmP at either plasma concentration of phosphorus. The results on all the patients investigated are detailed in Table II. The final column tabulates the ratio

Table I.-Typical Clearance Run Aiming at Two Steps of PlasmaPhosphate Concentration

\begin{tabular}{|c|c|c|c|c|c|c|c|c|c|}
\hline $\begin{array}{c}\text { Time } \\
(\text { a.m.) }\end{array}$ & $\begin{array}{l}\text { Urine } \\
\text { Vol. } \\
\text { (ml.) }\end{array}$ & $\begin{array}{l}\text { Urine } \\
\text { Vol. } \\
\text { (ml. } \\
\text { min.) }\end{array}$ & $\begin{array}{c}\text { Urine } \\
\text { Inulin } \\
\text { (mg./ } \\
\text { ml.) }\end{array}$ & $\begin{array}{c}\text { Plasma } \\
\text { Inulin } \\
\text { (mg./ } \\
100 \mathrm{ml} .)\end{array}$ & $\begin{array}{c}\text { G.F.R.R. } \\
\text { (mil. } \\
\text { min. }\end{array}$ & $\begin{array}{c}\text { Plasma } \\
\mathrm{PO}_{4} \\
\text { (mg:l } \\
\text { mi.) } \\
\end{array}$ & $\begin{array}{c}\text { Filtered } \\
\text { PO. } \\
\text { (mg.: } \\
\text { min.) } \\
\end{array}$ & $\begin{array}{l}\text { Urine } \\
\text { PO. } \\
\text { (mg.) } \\
\text { min.) }\end{array}$ & $\begin{array}{l}\operatorname{TmP} \\
\text { (min. } \\
\text { min.) }\end{array}$ \\
\hline $\begin{array}{l}5 \\
6 \\
6 \\
6.20 \\
7.5\end{array}$ & \multicolumn{3}{|c|}{$\begin{array}{l}\text { Passed night urine } \\
\text { Inulin infusion started } \\
100\left|\begin{array}{l}1 \cdot 7 \\
182\end{array}\right|\end{array}$} & & & 0.018 & & & \\
\hline $\begin{array}{l}7.25 \\
7.46 \\
8.5 \\
8.5\end{array}$ & $\begin{array}{c}262 \\
170 \\
68 \\
\mathrm{Ph}\end{array}$ & $\begin{array}{r}13.1 \\
8.1 \\
3.6 \\
\text { sphate }\end{array}$ & $\begin{array}{l}1,053 \\
1,068 \\
1,240 \\
\text { riming }\end{array}$ & $\begin{array}{r}16.5 \\
16.0 \\
15.4 \\
\text { tep II ar }\end{array}$ & $\begin{array}{r}63.8 \\
66.7 \\
80.5 \\
d \text { susta }\end{array}$ & \begin{tabular}{|l|l|}
0.0592 \\
0.0513 \\
0.0434 \\
ining infu
\end{tabular} & $\begin{array}{r}3.78 \\
3.42 \\
3.49\end{array}$ & $\begin{array}{l}2.97 \\
2.48 \\
2.66 \\
d\end{array}$ & $\begin{array}{l}1.81 \\
1.95 \\
1.83\end{array}$ \\
\hline $\begin{array}{l}8.25 \\
8.45 \\
9.5\end{array}$ & $\begin{array}{l}133 \\
200 \\
180\end{array}$ & $\begin{array}{r}6.6 \\
10.0 \\
9.0\end{array}$ & $\begin{array}{l}1,610 \\
1,460 \\
1,220\end{array}$ & $\begin{array}{l}18.0 \\
16.0 \\
14.0\end{array}$ & $\begin{array}{l}89.5 \\
911.0 \\
87.0\end{array}$ & $\mid \begin{array}{l}0.0734 \\
0.0740 \\
0.0746\end{array}$ & $\begin{array}{l}6.59 \\
6.75 \\
6.50\end{array}$ & $\begin{array}{l}5 \cdot 19 \\
5.14 \\
4.92\end{array}$ & $\begin{array}{l}1.38 \\
1.61 \\
1.68\end{array}$ \\
\hline
\end{tabular}

Mean G.F.R. $=80.1 \mathrm{ml} . / \mathrm{min} . \pm 10.4 \mathrm{ml}$. Mean TmP $=1.71 \mathrm{mg} . / \mathrm{min} . \pm 0.18 \mathrm{mg}$.

TABLE II.-Patients with Parathyroid Adenomata $(A)$ or Hyperplasia (H) Investigated Pre-operatively

\begin{tabular}{|c|c|c|c|c|c|c|c|c|c|}
\hline Patient & Ago & Sex & $\begin{array}{l}\text { Type } \\
\text { of } \\
\text { Gland }\end{array}$ & $\begin{array}{c}\text { Plasma } \\
\text { Ca. } \\
\text { (mg.l } \\
100 \mathrm{ml} .)\end{array}$ & $\begin{array}{c}\text { Plasma } \\
\text { P. } \\
\text { (mg.l } \\
100 \mathrm{ml} .)\end{array}$ & $\begin{array}{l}\text { Alk. } \\
\text { Phos- } \\
\text { phatase } \\
\text { (K.A.) } \\
\text { (Units/ } \\
100 \mathrm{ml} \text {.) }\end{array}$ & $\underset{\text { (min. }}{\text { G.F. }}$ & $\begin{array}{c}\text { TmP } \\
\text { (min.) } \\
\text { min.) }\end{array}$ & $\begin{array}{l}\text { Tmpl } \\
\text { G.F.R. } \\
\text { (mg.| } \\
\left.\text { ml. } \times 10^{3}\right)\end{array}$ \\
\hline \begin{tabular}{|c|}
1 \\
2 \\
3 \\
4 \\
5 \\
6 \\
7 \\
8 \\
99 \\
10 \\
11 \\
12 \\
13 \\
14
\end{tabular} & $\begin{array}{l}55 \\
49 \\
45 \\
40 \\
52 \\
48 \\
41 \\
43 \\
47 \\
61 \\
38 \\
40 \\
55 \\
57\end{array}$ & \begin{tabular}{|c|}
$\mathbf{M}$ \\
$\mathbf{F}$ \\
$\mathbf{M}$ \\
$\mathbf{M}$ \\
$\mathbf{F}$ \\
$\mathbf{P}$ \\
$\mathbf{M}$ \\
$\mathbf{F}$ \\
$\mathbf{F}$ \\
$\mathbf{P}$ \\
$\mathbf{P}$ \\
$\mathbf{F}$ \\
$\mathbf{F}$
\end{tabular} & $\begin{array}{l}\mathbf{A} \\
\mathbf{A} \\
\mathbf{A} \\
\mathbf{A} \\
\mathbf{A} \\
\mathbf{A} \\
\mathbf{A} \\
\mathbf{A} \\
\mathbf{A} \\
\mathbf{A} \\
\mathbf{A} \\
\mathbf{A} \\
\mathbf{H}\end{array}$ & $\begin{array}{l}14 \cdot 1 \\
12 \cdot 7 \\
12.0 \\
13 \cdot 6 \\
16 \cdot 2 \\
14.1 \\
12.9 \\
11 \cdot 8 \\
11.2 \\
12.3 \\
13 \cdot 4 \\
12.5 \\
11 \cdot 6 \\
11 \cdot 2\end{array}$ & $\begin{array}{l}2.6 \\
2.6 \\
2.2 \\
2.5 \\
1.8 \\
1.9 \\
2.0 \\
2.2 \\
2.3 \\
2.8 \\
1.9 \\
1.0 \\
2.7 \\
2.6\end{array}$ & $\begin{array}{r}14 \\
8 \\
7 \\
24 \\
10 \\
68 \\
5 \\
6 \\
12 \\
10 \\
12 \\
8 \\
10 \\
7\end{array}$ & $\begin{array}{l}60 \\
50 \\
70 \\
66 \\
50 \\
86 \\
75 \\
82 \\
38 \\
63 \\
80 \\
78 \\
78 \\
55\end{array}$ & $\begin{array}{l}0.78 \\
1.2 \\
1.0 \\
1.06 \\
0.75 \\
1.05 \\
1.1 \\
1.2 \\
0.64 \\
1.73 \\
1.19 \\
1.55 \\
3.10 \\
2.51\end{array}$ & $\begin{array}{l}13 \\
24 \\
14 \\
16 \\
15 \\
12 \\
15 \\
15 \\
16 \\
15 \\
15 \\
20 \\
40\end{array}$ \\
\hline
\end{tabular}

TmP/G.F.R., which measures the balance of glomerulo-tubular activity, the mean ratio in normals being about 38 . Four patients had TmP estimations made while they were receiving $150 \mathrm{mg}$. of cortisone daily as part of a test of parathyroid function. No significant change in the $\mathrm{TmP}$ was detected (Table III). The patients who had their TmP estimated postoperatively are listed in Table IV. As the TmP is higher with high glomerular filtration rates it is necessary to allow for this when comparing results at different filtration rates in the same subject. The factor obtained by dividing the TmP by the G.F.R. makes allowance for this and the percentage increase between the pre-operative and post-operative factors in patients are shown in Table IV. Significant increases in this parameter were observed. The regression line between the $\mathrm{TmP}$ and the glomerular filtration rate for the patients with renal failure is $y=0.03 x-0.11$ and for the normal subjects is $y=0.05 x-1.4$ (see Fig. below).

TABLE III.-Patients with Parathyroid Adenomata Investigated During Cortisone-suppression Test (150 mg. Cortisone Daily)

\begin{tabular}{|c|c|c|c|c|c|c|}
\hline Patient & Age & Sex & $\begin{array}{c}\text { G.F.R. } \\
\text { (mi... } \\
\text { min.) }\end{array}$ & $\begin{array}{c}\operatorname{TmP} \\
\text { (mi.). } \\
\text { min.) }\end{array}$ & $\begin{array}{c}\text { TmP } \\
\text { (G.F.R. } \\
\text { mg.l. } \\
\text { ml. } \times 10^{3} \text { ) }\end{array}$ & $\begin{array}{l}\underset{\text { TmP/G.F.R. }}{\text { before steroid }} \\
\underset{\text { after }}{\operatorname{TmP} / G . F . R .} \text { steroid }\end{array} \times 100$ \\
\hline $\begin{array}{l}5 \\
6 \\
7 \\
8\end{array}$ & $\begin{array}{l}52 \\
48 \\
41 \\
43\end{array}$ & $\begin{array}{l}\mathbf{F} \\
\mathbf{F} \\
\mathbf{F}\end{array}$ & $\begin{array}{l}46 \\
80 \\
78 \\
80\end{array}$ & $\begin{array}{l}0.7 \\
1 \cdot 0 \\
1.25 \\
1 \cdot 10\end{array}$ & $\begin{array}{l}15.0 \\
12.5 \\
16.0 \\
13.8\end{array}$ & $\begin{array}{c}100 \\
104 \\
94 \\
108\end{array}$ \\
\hline
\end{tabular}

TABLE IV.-Patients Investigated Post-operatively

\begin{tabular}{c|c|c|c|c}
\hline Patient & $\begin{array}{c}\text { G.F.R. } \\
\text { (ml./min.) }\end{array}$ & $\begin{array}{c}\text { TmP } \\
(\mathbf{m g} . / \mathrm{min} .)\end{array}$ & $\begin{array}{c}\text { Tmp/G.F.R. } \\
(\text { mg.l } \\
\left.\text { ml. } \times 10^{3}\right)\end{array}$ & $\begin{array}{c}\text { TmP/G.F.R. post op. } \\
\text { TmP/G.F.R. pre op. }\end{array}$ \\
\hline 1 & 70 & 2.3 & 33 & 254 \\
3 & 64 & 1.9 & 29 & 207 \\
4 & 73 & 4.0 & 54 & 338 \\
5 & 52 & 1.6 & 31 & 207 \\
6 & 82 & 2.1 & 26 & 217 \\
8 & 90 & 3.8 & 42 & 280 \\
\hline
\end{tabular}

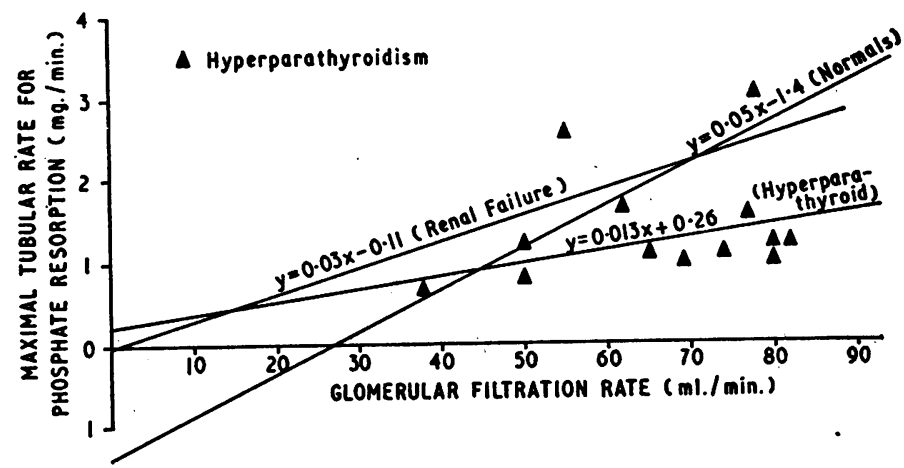

Showing the regression line $(y=0.013 x+0.26)$ for the TmP plotted against the glomerular filtration rate in hyperparathyroid patients and also the regression line for normal subjects $(y=0.05 x-1.4)$ and patients with renal failure $(y=0.03 x-0.11)$.

\section{Discussion}

Our findings here confirm those of Hiatt and Thompson (1957) and Hyde et al. (1960), who have shown that functioning parathyroid adenomata depress the maximal tubular resorptive rate for inorganic phosphate. The two patients (13 and 14) whose resorptive rate is within the lower end of the normal range did not have adenomata but hyperplasia of all four parathyroid glands. Patient 13 also had renal calculi on one side with delayed emptying of the renal pelvis, and the plasma inorganic phosphorus concentration reached $12.5 \mathrm{mg} . / 100 \mathrm{ml}$. -these factors may have increased the observed TmP.

The consistency of the results is in part due to ensuring that all patients had a constant dietary intake of phosphorus of between 1 to $1.5 \mathrm{~g}$. a day for at least four days before the test. 
There is no doubt that the TmP is affected by diet, and Hiatt and Thompson (1957) showed that a previously high phosphate diet of $2 \mathrm{~g}$. a day or greater would reduce the TmP. Lewis and Ford (1961) showed that paraminohippuric acid (P.A.H.) given by Hiatt and Thompson (1957) to determine the renal blood flow in many of their subjects also affects phosphate excretion and this may account for the wide scatter of the TmP in normal subjects when P.A.H. was given as well as phosphate.

As far as could be judged there were no other hormonal disturbances in our patients apart from the parathyroid, and it was assumed that the hormonal background remained constant during the various tests on each patient. It has been shown that thyroid and growth hormones also affect phosphate excretion.

Phosphate and creatinine clearances at normal plasma concentrations have been used as an indirect assessment of tubular function and the tubular resorption rate has been determined by McGeown (1957) and Shaaf and Kyle (1954). Nordin and Fraser (1960) have tried to improve this measurement by computing the phosphate excretion index. Unfortunately they do not appear to have given any weight to dietary changes or have ensured that all subjects had a constant phosphate diet. This may account for the extremely wide range of normal values that has been found by Hodgkinson (1961) and Yendt and Jaworski (1961) to overlap those of patients with proved hyperparathyroidism. In view of this, Hyde et al. (1962) determined the renal-phosphorus threshold by raising the plasma inorganic phosphate in the linear manner. They found a definite difference between the patients with parathyroid tumours and the normal subjects. However, Anderson and Parsons (1963a), using the present method of determining the TmP, demonstrated in normal subjects a relationship between glomerular filtration rate and TmP suggesting that it was related to the functioning renal mass. Thus, in interpreting the TmP of these patients who have impaired renal function, it is important to make allowance for their reduced glomerular filtration rate.

The reduction in glomerular filtration rate is common to all the patients studied here and confirms the work of Edvall (1958). He also studied inulin clearances and TmP P.A.H. and showed that the ratio was higher in patients with hyperparathyroidism than in other hypercalcaemic states and in patients with renal stones from other causes. Thus there appears to be a tubular alteration in the handling of P.A.H. as well as phosphate. However, the TmP is useful even if renal failure is present as this series shows. It is also possible that an adenoma may not secrete continuously and during periods of inactivity all tests would be expected to be normal. Thus one normal result is not adequate for diagnosis in this situation.

A significant difference was found between the regression line between the TmP and the glomerular filtration rate of normal subjects and the patients who had parathyroid adenomata. However, patients with renal failure from other causes have a TmP that is above the regression line for normal subjects (Anderson and Parsons, 1963b). In spite of reduction of the TmP due to advancing renal failure, that of the hyperparathyroid patients was still significantly lower than that of the patients with renal failure or normal subjects. Whether this test will be of any use as a diagnostic tool in secondary as well as primary hyperparathyroidism is doubtful because of the difficulty in interpreting indirect evidence of this kind without support from operative findings or by another method such as determining the concentration of parathyroid hormone in the blood.
Four patients had the TmP determined before and at the end of a cortisone-suppression test when they were taking $150 \mathrm{mg}$. of cortisone a day. Cortisone was already known to depress the tubular absorption of phosphate in dogs (Pitts and Alexander, 1944) and in man (Anderson and Foster, 1959). In these patients there was no significant change in the TmP, so that cortisone, in this situation, seems unable to increase the phosphaturia induced by parathormone and lower the TmP.

It would appear, therefore, that the actions of parathyroid hormone and cortisone may well be on the same final common pathway so that when the capacity of this pathway for the transfer is maximally depressed by the former, cortisone-and perhaps other hormones also-are unable to alter it.

Five patients who had their TmP determined up to a year after the operation show a remarkable recovery of the tubular capacity to reabsorb phosphate. However, there was no statistically significant improvement in their glomerular filtration rate. Edvall (1958) reported an improvement in the glomerular filtration rate of some of his patients after operation, but this was not significant. The tubular changes in the reabsorption of phosphorus in patients tended to improve with the removal of the adenoma. However, so far as glomerular damage is concerned it appears to be important to make the diagnosis early to prevent glomerular damage by the hypercalcaemia, as it is largely irreversible.

\section{Summary}

The maximal tubular resorptive capacity for phosphate was significantly reduced in 12 of 14 patients with hyperparathyroidism below that of normal subjects and patients with renal failure from other causes. The two patients without a significant reduction of TmP had moderate parathyroid hyperplasia only and one had delayed emptying of one kidney in addition, which may have influenced the result. Six patients who were tested again after removal of their parathyroid adenoma showed a return towards normal values. Cortisone (150 mg. daily) failed to reduce the TmP further in four of the hyperparathyroid patients.

We wish to thank Dr. Clifford Hoyle, director of the Medical Unit, for his encouragement; and also Miss $M$. Carden, the dietitian, Sister Betty Drane, head of the nursing team, and Miss $M$. Wall, technician, for their constant help. We also wish to thank the Research Committee of King's College Hospital for financial support.

\section{REFERENCES}

Albright, F., and Ellsworth, R. (1929). 7. clin. Invest., 7, 183.

Anderson, I. (1955a). Proc. roy. Soc. Med., 48, 779 . (1955b). F. Physiol. (Lond.), 130, 268.

and Foster, J. B. (1959). Clin. Sci., 18, 437.

and Parsons, V. (1963a). Clin. Sci. In press.

(1963b). In press.

Collip, J. B., Pugsley, L. I., Selye, H., and Thomson, D. L. (1934). Brit. 7. exp. Path., 15, 335 .

Edvall, C. A. (1958). Acta chir. scand., Suppl. No. 229, 1-56.

Hiatt, $H$. H., and Thompson, D. D. (1957). F. clin. Invest., 36, 557.

Hodgkinson, A. (1961). Clin. Sci., 21, 125.

Hyde, R. D., Vaughan Jones, R., McSwiney, R. R., and Prunty, F. T. G. (1960). Lancel, 1, 250.

Lewis, J., and Ford, R. V. (1961). F. Lab. clin. Med., 57, 546.

Lloyd, H. M., Rose, G. A., and Smeenk, D. (1962). Clin. Sci., 22, 353. McGeown, M. G. (1957). Ibid., 16, 297.

Nordin, B. E. C., and Fraser, R. (1960). Lancet, 1, 947.

Pitts, R. F., and Alexander, R. S. (1944). Amer. F. Physiol., 142, 648.

Schaaf, M., and Kyle, L. H. (1954). Amer. J. med. Sci., 228, 262.

Sirota, J. H. (1953). Fed. Proc., 12, 133.

Yendt, E. R., and Jaworski, L. F. (1961). In The Parathyroids, edited R. O. Greep and R. V. Talmage, p. 439. C. Thomas, Springfield, Illinois. 